\title{
Peresepan Obat "Off-label" Pada Anak Dengan Penyakit Infeksi Saluran Pernapasan Akut
}

\author{
Eri Destin Anggraini ${ }^{a, 1}$, Oki Nugraha Putra ${ }^{a, 2^{*}}$, Ana Khusnul Faizah ${ }^{a, 3}$ \\ ${ }^{a}$ Program Studi Farmasi, Universitas Hang Tuah, Surabaya \\ 1 oki.nugraha@hangtuah.ac.id* \\ *korespondensi penulis
}

\begin{tabular}{|c|c|}
\hline INFO ARTIKEL & ABSTRAK \\
\hline $\begin{array}{l}\text { Diterima : } \\
\text { 23-I2-2020 } \\
\text { Revisi : } \\
\text { 26-I2-2020 } \\
\text { Disetujui : } \\
\text { O6-OI-202I }\end{array}$ & $\begin{array}{l}\text { Infeksi Saluran Pernapasan Akut (ISPA) termasuk penyakit yang banyak terjadi } \\
\text { di Indonesia terutama pada usia anak. Pada populasi anak berisiko mendapatkan } \\
\text { peresepan obat off-label dikarenakan terbatasanya data efikasi obat untuk anak. } \\
\text { Penggunaan obat off-label meningkatkan risiko efek yang tidak dikehendaki. } \\
\text { Penelitian ini bertujuan untuk mengevaluasi penggunaan obat secara off-labe } \\
\text { pada peresepan pasien ISPA anak. Penelitian ini merupakan penelitian deskriptif } \\
\text { observasional dengan menggunakan desain cross-sectional. Pengumpulan data }\end{array}$ \\
\hline $\begin{array}{l}\text { Kata kunci: } \\
\text { Obat off-label; } \\
\text { ISPA; } \\
\text { Peresepan; } \\
\text { Anak. }\end{array}$ & $\begin{array}{l}\text { menggunakan peresepan obat dengan diagnosis ISPA pada anak usia } 0-18 \text { tahun. } \\
\text { Penelitian ini dilakukan pada bulan November } 2019 \text { sampai dengan Februari } \\
2020 \text {. Pada' penelitian ini didapatkan } 124 \text { resep dengan diagnosis ISPA. } \\
\text { Penggunaan obat off-label pada peresepan penyakit infeksi saluran pernapasan } \\
\text { akut untuk pasien anak sebesar } 23 \% \text { dengan kategori off-label usia (I5,67\%), } \\
\text { off-label dosis }(5,70 \% \text { ), off-label rute pemberian (I,22\%) dan off-label indikasi } \\
\text { (0,40\%). Jenis obat off-label paling banyak diresepkan untuk ISPA anak adalah } \\
\text { antihistamin klorfeniramin maleat. Berdasarkan hasil penelitian yang telah } \\
\text { dilakukan dapat disimpulkan bahwa penggunaan obat off-label pada penyakit } \\
\text { ISPA anak cukup tinggi. Farmasis dan dokter dapat berkolaborasi untuk } \\
\text { pemantauan penggunaan obat yang tergolong off-label. Penelitian lanjutan } \\
\text { diperlukan untuk melihat korelasi atau faktor risiko yang berpotensi } \\
\text { meningkatkan penggunaan off-labelpada ISPA anak. }\end{array}$ \\
\hline
\end{tabular}

Keywords:

Off-label drugs;

Acute Respiratory Tract ;

Infection;

Prescribing;

Children.

\section{ABSTRACT}

Acute respiratory tract infections (ARTI) is a disease that often occurs in Indonesia, especially in children. The population of children is high risk of receiving off-label prescription drugs. The use of off-label drugs increases the risk of undesirable effects. This study was aimed to evaluate the off-label use of drugs in prescribing with acute respiratory tract infection. This research is a descriptive observational study using a cross-sectional design. Data was collected by the prescription in children aged 0-I8 years old with acute respiratory tract infection. This study was conducted from November 2019 to February 2020. In this study, I24 prescriptions were obtained with a diagnosis of ARTI. The use of off-label drugs was $23 \%$ with the off-label age category (I5.67\%), off-label dose (5.70\%), off-label route of administration (1.22\%) and off-label indication (0.40\%). The type of off-label drug most commonly prescribed in children with ARTI is chlorpheniramine maleate. It can be concluded that the use of off-label drugs in children with ARTI disease is quite high. Pharmacists and clinicians should collaborate each other to monitor the use of drugs that are classified as off-label. Further research is needed to analyze correlations or risk factors that potentially may increase off-label use in children with ARTI.

This is an open access article under the CC-BY-SA license. 


\section{Pendahuluan}

Infeksi Saluran Pernapasan Akut (ISPA) merupakan infeksi yang menyerang saluran pernapasan manusia dengan jumlah penderita paling banyak ditemukan pada usia balita. ISPA yang tidak ditangani dengan baik akan menyebabkan komplikasi pneumonia yang merupakan penyebab utama kematian pada bayi dan balita (Depkes RI, 2009). Berdasarkan data Riskesdas 2018, menyebutkan bahwa prevalensi kasus ISPA di Indonesia pada tahun 2013 sebesar $25,0 \%$. Tingkat mortalitas penyakit ISPA sangat tinggi pada balita, anak dan orang lansia terutama di negara berkembang termasuk Indonesia (Kemenkes RI, 20I8)

Pada terapi ISPA, pasien dapat diberikan terapi antibiotik dan terapi pendukung untuk mengurangi keluhan atau simptom yang timbul. Banyaknya variasi penggunaan obat pada pasien ISPA anak akan berdampak pada penggunaan obat off-label. Off-label adalah penggunaan obat untuk indikasi, kontraindikasi, usia, dosis, dan rute pemberian yang tidak disebutkan dalam label produk yang telah disetujui oleh Food and Drug Administration (FDA) (Tefera et al, 2017). Prevalensi penggunaan obat off-label pada populasi anak berdasarkan hasil dari beberapa studi yang dilakukan berkisar antara 3-75\% (Purwadi et al, 2014). Dari segi peresepan obat off-label pada anak, diketahui bahwa $25 \%$ merupakan pasien rawat jalan dan $60 \%$ merupakan pasien rawat inap di rumah sakit (Ballard et al, 2013).

Penggunaan obat secara off-label dapat diberikan kepada anak, meskipun masalah keamanan dan efikasi obat dapat menimbulkan risiko yang diakibatkan respon obat dalam tubuh yang tidak terduga. Pada anak dan dewasa mempunyai perbedaan fisiologis, sehingga pada usia anak dapat terjadi perubahan profil farmakokinetik obat tertentu (Czarniak et al, 2015). Akan tetapi, respon ini dapat berubah seiring dengan pertambahan usia anak (Kimland dan Odlind, 20I2). Penggunaan obat offlabel meningkatkan risiko efek obat yang tidak dikehendaki atau Adverse drug events (ADEs). Adverse drug events (ADEs) merupakan kejadian yang tidak diinginkan yang berkaitan dengan pengobatan pada pasien, termasuk adverse drug reactions (ADRs) dan medication errors (MEs). Penggunaan obat off-label pada populasi anak dapat menyebabkan peningkatan risiko medication error (Tefera et al, 2017).

Penelitian oleh Setyaningrum et al, menyebutkan bahwa penggunaan obat off-label pada usia anak cukup tinggi, yakni sebesar $21 \%$ dan didominasi off-label pada kategori usia sehingga perlu dilakukan pengawasan terkait risiko penggunaan obat (Setyaningrum et al, 2017). Berdasarkan latar belakang tersebut, dilakukan penelitian untuk menganalisis penggunaan obat secara off-label pada pasien ISPA anak, ditinjau dari dari kategori off-label indikasi, kontraindikasi, usia, dosis, dan rute pemberian.

\section{Metode}

Rancangan Penelitian
Penelitian ini merupakan penelitian
deskriptif prospektif observasional dengan
menggunakan desain cross-sectional. Data pada
penelitian ini menggunakan lembar resep yang
berisikan obat dengan diagnosis ISPA pada pasien
anak. Penelitian ini telah mendapatkan ijin penelitian
dari Dinas Kesehatan Kota Surabaya dengan nomor:
072/29248/436.7.2/2019

\section{Sampel, teknik sampling dan kriteria inklusi}

Sampel pada penelitian ini ialah resep pasien anak dengan diagnosis ISPA. Sampel diambil menggunakan teknik consecutive sampling, yaitu resep yang memenuhi tujuan penelitian atau kriteria inklusi akan dimasukan sebagai sampel penelitian sampai dengan waktu yang diperlukan terpenuhi. Kriteria inklusi pada penelitian ini ialah pasien ISPA anak dengan umur 0 hingga I8 tahun. Besar sampel yang dibutuhkan pada penelitian ini dihitung menggunakan rumus sampel proporsi Cross sectional sebagai berikut :

$$
\begin{aligned}
& \text { Keterangan : } \\
& \mathrm{n} \quad=\text { jumlah sampel } \\
& \mathrm{n}=\frac{\mathrm{Z}^{2}{ }_{1-2 / 2} \mathrm{p}(1-\mathrm{p}) \mathrm{N}}{\mathrm{d}^{2}(\mathrm{~N}-1)+\mathrm{Z}^{2}{ }_{1-\alpha_{2}} \mathrm{p}(1-\mathrm{p})} \\
& \mathrm{N}=\text { jumlah populasi } \\
& \mathrm{P} \quad=\text { proporsi di populasi }(0,5) \\
& \mathrm{d}=\text { derajat akurasi }(0, \mathrm{I}) \\
& Z_{1-\alpha / 2}=\text { nilai baku distribusi normal pada } \alpha \\
& \text { tertentu }(I, 96)
\end{aligned}
$$

Dengan jumlah populasi pasien ISPA (N) anak pada tahun 2019 di ketiga Puskesmas sebesar 536 diperoleh jumlah sampel minimal sebanyak 8I subyek atau lembar resep

\section{Tempat dan Waktu Penelitian}

Penelitian ini dilakukan di Puskesmas Wiyung, Puskesmas Wonokusumo dan Puskesmas Jagir Surabaya pada bulan November 2019 Februari 2020. 


\section{Alat dan Bahan}

Alat penelitian berupa lembar pengumpul data peresepan untuk melakukan kajian obat offlabel pada pasien ISPA anak. Identifikasi peresepan mengacu pada British National Formulary for Children (BNFC) tahun 2018-2019 dan BNFC tahun 2019-2020.

\section{Analisis Data}

Analisis data berupa data demografi dan penggunaan Off-label kategori usia, indikasi, kontraindikasi, dosis dan rute pemberian disajikan dalam bentuk tabel dan diagram. Data numerik disajikan sebagai rata-rata $\pm \mathrm{SD}$.

\section{Hasil dan Pembahasan}

Demografi Pasien

Telah dilakukan penelitian terkait penggunaan obat off-label pada Penyakit Infeksi Saluran Pernapasan Akut pada anak. Didapatkan I24 lembar resep pasien ISPA anak yang memenuhi kriteria inklusi. Data demografi pasien ISPA anak seperti ditunjukkan pada tabel I

Tabel I. Demografi Pasien

\begin{tabular}{|c|c|c|c|}
\hline Demografi pasien & $(n=I 24)$ & $\begin{array}{l}\text { Persentase } \\
(\%)\end{array}$ & $\begin{array}{c}\text { Nilai } \\
\boldsymbol{\alpha}\end{array}$ \\
\hline Jenis kelamin & & & \\
\hline Laki-laki & 63 & 50,80 & $0,928^{*}$ \\
\hline Perempuan & $6 I$ & 49,20 & \\
\hline $\begin{array}{l}\text { Usia (Mean } \pm \mathrm{SD} \text { ), tahun } \\
\text { Bayi: } 0,13-\mathrm{I}, 66 \\
\text { Anak: } 2-\mathrm{I} 2 \\
\text { Remaja:I2 - I8 }\end{array}$ & $\begin{array}{c}34(0,9 \pm 0,4) \\
68(4,7 \pm 2,4) \\
22(14,0 \pm 1,9)\end{array}$ & $\begin{array}{l}27,42 \\
54,84 \\
17,74\end{array}$ & \\
\hline
\end{tabular}

${ }^{*}$ Uji Binomial

Pada pasien ISPA anak berdasarkan jenis kelamin, diperoleh jenis kelamin laki-laki jumlahnya lebih banyak dibandingkan perempuan meskipun secara statistik tidak berbeda bermakna ( $\mathrm{P}>0.05)$. Pada penelitian ini pasien ISPA anak ditemukan paling banyak pada rentang usia 2 - I2 tahun yaitu sebanyak 68 pasien. Hasil ini sejalan dengan penelitian oleh Tefera et al, yang menyebutkan bahwa usia yang paling banyak ditemukan pada pasien ISPA anak adalah usia 2-6 tahun sebanyak 70 $(28,8 \%)$ dan usia 6-I3 tahun sebanyak 64 (26,3\%) dari total 243 pasien anak (Tefera et al, 2017). Penelitian ini menunjukkan jumlah pasien ISPA lebih banyak terdapat pada usia balita. Pada dasarnya usia balita antara I-24 bulan cukup rentan terhadap timbulnya berbagai macam penyakit infeksi. Hal ini dikaitkan dengan struktur dan anatomi organ tubuh serta sistem kekebalan tubuh yang belum berkembang sempurna. Pasien ISPA anak cenderung terjadi pada anak laki-laki dibandingkan perempuan. Dilihat dari faktor lingkungan, anak dengan jenis kelamin laki-laki pada umumnya lebih banyak beraktivitas di luar rumah, lebih suka bermain di tempat kotor dan berdebu sehingga lebih rentan terhadap penyakit (Setyaningrum et al, 2017).

\section{Profil Penggolongan Obat ISPA anak}

Berdasarkan data yang diperoleh maka obat untuk Infeksi Saluran Pernapasan Akut pada anak dapat diklasifikasikan berdasarkan kelas terapi seperti ditunjukkan pada tabel 2 .

Tabel 2 Profil Penggolongan Obat ISPA Anak Berdasarkan Kelas Terapi

\begin{tabular}{lccc}
\hline Kelas Terapi & Nama Obat & $\begin{array}{c}\text { Jumlah } \\
(\%)\end{array}$ & $\begin{array}{c}\text { Persentase } \\
(\%)\end{array}$ \\
\hline Antihistamin & Klorfeniramin maleat & II $4(25,47)$ & \\
& Prednison & I7 $(3,79)$ & \\
& Dexamethason & I0 $(2,23)$ & 32,37 \\
& Cetirizin & $3(0,66)$ & \\
& Loratadin & $\mathrm{I}(0,22)$ & \\
\hline
\end{tabular}


Tabel 2 Profil Penggolongan Obat ISPA Anak Berdasarkan Kelas Terapi

\begin{tabular}{lccc}
\hline Kelas Terapi & Nama Obat & $\begin{array}{c}\text { Jumlah } \\
(\%)\end{array}$ & $\begin{array}{c}\text { Persentase } \\
(\%)\end{array}$ \\
\hline Batuk & Gliseril guaiacolat & I00 (22,32) & 26,34 \\
& Ambroxol & I8 (4,02) & \\
Antipiretik & Parasetamol & I04 (23,2I) & $23,2 \mathrm{I}$ \\
Suplemen & B kompleks & $56(\mathrm{I} 2,50)$ & $\mathrm{I} 2,50$ \\
Antiasma & Salbutamol & I3 (2,90) & 2,90 \\
Antibiotik & Amoxicillin & I2 (2,68) & 2,68 \\
\hline \multicolumn{5}{c}{ Jumlah } & 448 & I00 \\
\hline
\end{tabular}

Pada penelitian ini diperoleh 448 total penggunaan obat dari I24 resep ISPA anak. Pada profil pengobatan yang paling banyak digunakan ialah golongan antihistamin dengan klorfeniramin maleat yang paling banyak diresepkan. Salah satu gejala ISPA ialah hipersensitifitas pada saluran pernapasan sehingga penggunaan antihistamin diijinkan untuk digunakan karena mampu menekan respon alergi pada saluran napas serta dapat mengurangi gejala alergi pada anak (Fitzsimons et al, 2015). Salah satu antihistamin yang biasa diresepkan ialah klorfeniramin maleat yang merupakan golongan sedating antihistamin yang bekerja dengan cara menghambat neurotransmitter histamin pada reseptor CNS HI (Craig et al, 2016). Antihistamin HI generasi pertama lebih mudah menembus ke dalam sawar darah otak sehingga menyebabkan efek sedasi atau kantuk, kelelahan dan gangguan konsentrasi anak (Church et al, 2013). Efek antihistamin juga dapat menimbulkan mulut kering. Klorfeniramin maleat banyak dipakai pada pengobatan ISPA dibandingkan dengan antihistamin lainnya dikarenakan harganya yang murah dan mudah diperoleh dengan efek samping yang minimal.

Pada kondisi pernapasan yang terganggu dapat mengubah komposisi dan sifat lendir saluran napas. Lendir pernapasan yang berlebihan dapat menghambat mucociliary clearance (MCC) dan berfungsi sebagai pemicu batuk. Ekspektoran digunakan sebagai pengobatan batuk akibat hipersekresi lendir dengan mekanisme peningkatan hidrasi lendir dan pembersihan dari saluran pernapasan (Albrecht et al, 2017). Penelitian oleh Richter menyebutkan bahwa gliceril guaicolat (GG) merupakan obat ekspektoran yang merangsang reseptor aferen di mukosa lambung yang secara refleks meningkatkan sekresi kelenjar epitel pernapasan dengan meningkatkan drainase saluran pernapasan serta mengurangi sekresi bronkial, melumasi membran saluran pernapasan yang teriritasi melalui peningkatan aliran mukosa, dan memfasilitasi menurunkan viskositas lendir kental (Richter, 20I4).

Gejala lain yang juga menyertai ISPA ialah peningkatan suhu tubuh atau demam sehingga diberikan obat analgesik antipiretik. Parasetamol merupakan obat analgetik dan antipiretik yang digunakan untuk menghilangkan rasa sakit dengan intensitas sedang, seperti yang biasanya terjadi pada sakit kepala dan juga banyak digunakan sebagai obat antipiretik untuk mengurangi demam (Shankar, 20I4). Secara klinis dosis parasetamol sebesar I5 $\mathrm{mg} / \mathrm{kg}$ merupakan pilihan obat yang aman dan efektif untuk pengobatan nyeri dan demam pada anak (de Martino et al, 2015).

Pada penelitian ini Puskesmas di Surabaya mengikuti panduan Manajemen Terapi Bayi Sakit (MTBS), sehingga dalam penatalaksanaan ISPA bukan pneumonia tidak diberikan antibiotik. Berdasarkan diagnosis dokter bahwa balita penderita ISPA bukan pneumonia merupakan penderita dengan keluhan batuk pilek biasa dan demam, sehingga pemberian obat bertujuan untuk mengurangi keluhan dan perlu disampaikan kepada orang tua jika ditemukan batuk lebih dari 3 minggu, maka disarankan untuk dilakukan pemeriksaan lebih lanjut (Kemenkes RI, 20II). Pada penatalaksanaan ISPA sedang atau pneumonia sedang sesuai dengan MTBS, dapat diberikan tambahan terapi antibiotik. Pada penelitian ini, antibiotik yang diberikan pada peresepan ISPA anak ialah amoksisilin seperti yang ditunjukan pada tabel 2. Pada panduan MTBS, kotrimoksazol merupakan antibiotik pilihan pertama sedangkan amoksisilin ialah antibiotik pilihan kedua. Meskipun demikian, penelitian yang dilakukan oleh Rajesh et al, menyatakan bahwa tingkat kesembuhan pasien anak dengan ISPA lebih tinggi pada kelompok yang diberikan amoksisilin sebesar 91,91\% dibandingkan pada kelompok yang mendapatkan kotrimoksazol, yakni sebesar 60,95\% (Rajesh et al, 2013). 
Pada penelitian ini, berdasarkan penggunaan obat Infeksi Saluran Pernapasan Akut pada anak, peresepan obat secara on label lebih banyak yaitu sebesar 77\% dibandingkan kategori off-label sebesar 23\%. Dari 124 resep, terdapat II3 dari 448 total obat yang termasuk dalam kategori off-label yang meliputi kategori off-label usia, off-label dosis, off-label cara pemberian dan off-label indikasi, sedangkan untuk kategori offlabel kontraindikasi tidak ditemukan pada penelitian ini. Distribusi penggunaan obat off-label ini dapat dilihat pada tabel 3.

Tabel 3. Distribusi Penggunaan Obat Off-label

\begin{tabular}{lcc}
\hline \multicolumn{1}{c}{ Kategori } & Jumlah & Persentase (\%) \\
\hline Usia & 77 & I5,67 \\
Dosis & 28 & 5,70 \\
Rute pemberian & 6 & 1,22 \\
Indikasi & 2 & $0,4 \mathrm{I}$ \\
\hline Jumlah & $\mathrm{II} 3$ & 23 \\
\hline
\end{tabular}

Obat-obat yang termasuk ke dalam obat offlabel pada penelitian ini yaitu Klorfeniramin maleat, gliseril guaiakolat, paracetamol, salbutamol, vitamin B kompleks dan zink. Penelitian ini sejalan dengan penelitian oleh Setyaningrum et al, menyebutkan bahwa pada peresepan obat untuk anak di sejumlah Apotek di kota Yogyakarta, ditemukan peresepan dalam kategori off-label sebesar 3 1,19\% yang terdiri dari off-label dosis (I5,45\%), off-label usia (I I,66\%), off-label indikasi (3,79\%), dan off-label cara pemberian $(0,29 \%)$, sedangkan untuk kategori off-label dosis dan off-label kontraindikasi tidak ditemukan adanya kasus off-label (Setyaningrum et al, 2019). Penelitian ini juga sejalan dengan hasil penelitian yang dilakukan oleh Akbar et al, yang menyebutkan bahwa pada peresepan obat untuk anak di Puskesmas Sleman, ditemukan obat dalam kategori off-label sebesar 20,87\%, yang terdiri dari off-label cara pemberian (16,50\%), off-label indikasi $(2,69 \%)$ dan off-label usia (I,68\%), sedangkan untuk kategori off-label dosis dan off-label kontraindikasi tidak ditemukan adanya kasus offlabel (Akbar et al, 2017).

Setelah dilakukan distribusi penggunaan obat off-label didapatkan jenis kategori off-label terbanyak adalah off-label usia. Obat dikategorikan off-label usia yaitu obat-obatan yang penggunaannya diluar rentang usia yang telah disetujui. Distribusi penggunaan off-label berdasarkan kategori usia seperti ditunjukan pada tabel 4.

Tabel 4. Profil Penggunaan Obat Off-label Kategori Usia

\begin{tabular}{|c|c|c|}
\hline Nama Obat & Penggunaan Resmi & Jumlah \\
\hline $\begin{array}{l}\text { Klorfeniramin } \\
\text { maleat }\end{array}$ & 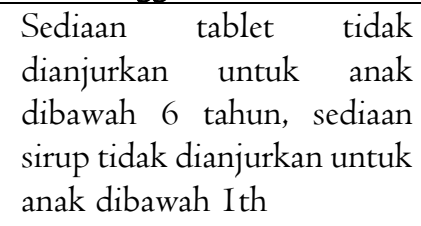 & 70 \\
\hline Salbutamol & $\begin{array}{l}\text { Sediaan oral tablet dan sirup } \\
\text { tidak dianjurkan untuk anak } \\
\text { dibawah } 2 \text { tahun }\end{array}$ & 7 \\
\hline & Jumlah & 77 \\
\hline
\end{tabular}

(Sumber : British National Formulary for Children, 2019-2020)

Obat yang dikategorikan kedalam off-labelusia sebagian besar adalah obat batuk pilek pada anak meliputi antihistamin dan batuk. Klorfeniramin maleat merupakan jenis obat paling banyak diidentifikasi sebagai off-label usia dan off-label dosis. Klorfeniramin maleat dibatasi pada anak usia kurang dari 6 tahun sedangkan dalam penelitian ini klorfeniramin maleat diberikan dalam bentuk puyer untuk 6 pasien anak dengan usia kurang dari 2 tahun. Antihistamin efektif dalam menghilangkan gejala rinitis alergi seperti hidung tersumbat dan mata berair, karena efek antikolinergiknya. Pada penggunaan klorfeniramin maleat pada anak usia di bawah 6 tahun, dapat menimbulkan efek samping maupun efek yang tidak diinginkan termasuk midriasis, sedasi, mata kering, mulut kering, konstipasi dan retensi urin (Malone et al, 2017).

Salbutamol merupakan obat golongan Beta 2agonis yang berperan pada tatalaksana asma atau Chronic obstructive pulmonary disease (COPD). Salbutamol yang diberikan secara per oral memiliki efek bronkodilator yang lebih lambat sehingga memiliki risiko tertelan secara tidak sengaja oleh anak dibawah 2 tahun. Terapi dengan oral bronkodilator tidak dianjurkan karena mula kerja obat (onset of action) yang lebih lambat dan kejadian efek samping 
yang lebih tinggi dibandingkan dengan rute inhalasi (GINA, 20I4). Meskipun risiko tertelannya kecil, namun komplikasi yang mungkin terjadi termasuk hipokalemia, hipoglikemia, kegelisahan dan takikardia (British Thoracic Society, 20I4). Efek samping salbutamol oral yang dapat terjadi yakni gemetar, takikardia, dan vasodilatasi perifer pada anak-anak yang menerima salbutamol pada dosis yang lebih besar (Andrzejowski et al, 2016).

Obat yang dikategorikan sebagai obat off-label dosis jika obat dikonsumsi tidak sesuai dengan dosis yang tercantum pada literatur seperti ditunjukkan pada tabel 5

Tabel 5. Profil Penggunaan Obat Off-label Kategori Dosis

\begin{tabular}{llc}
\hline \multicolumn{1}{c}{ Nama Obat } & Penggunaan Resmi & Jumlah \\
\hline Gliseril & $\begin{array}{l}\text { usia }<2 \text { tahun, } \\
\text { guaiacolat }\end{array}$ & $\begin{array}{l}\mathrm{I} 2 \mathrm{mg} / \mathrm{kg} / \text { hari oral } \\
\text { dalam } 6 \text { dosis }\end{array}$ \\
& $\begin{array}{l}\text { terbagi } \quad \text { max } \\
\text { Kx/hari) }\end{array}$ \\
Klorfeniramin & Usia I - 23 bulan & 9 \\
maleat & $\begin{array}{l}\text { Img, 2xI } \\
\text { (max 2mg) }\end{array}$ \\
Ambroxol & Usia 6 - I2 tahun & 7 \\
& I5 - 30mg, 2-3xI \\
& po \\
\hline & Jumlah & \\
\hline
\end{tabular}

Pada penelitian ini obat yang paling banyak dikategorikan ke dalam off-label dosis yaitu gliseril guaiacolat (GG) dengan dosis yang diberikan melebihi dosis yang dianjurkan sesuai dengan usia anak. Penggunakan gliseril guaiacolat untuk usia kurang dari 2 tahun disarankan menggunakan dosis $12 \mathrm{mg} / \mathrm{kg} /$ hari per oral dalam 6 dosis terbagi (max $4 \mathrm{x} /$ hari), sedangkan pada penelitian ini anak usia dibawah 2 tahun mendapat dosis lebih dari yang telah disarankan. Efek gliseril guaiacolat tidak hanya mempengaruhi konsistensi lendir (misalnya, meningkatkan hidrasi lendir atau mengubah viskoelastisitas), tetapi obat tersebut secara langsung atau tidak langsung menargetkan berbagai proses, termasuk penghambatan sensitivitas refleks batuk (Albrecht et al, 2017). Overdosis pada gliseril guaiacolat menghasilkan efek toksik yang rendah. Efek samping yang mungkin ditimbulkan yakni mual dan muntah

Obat dikategorikan sebagai obat off-label rute pemberian jika obat dikonsumsi tidak sesuai dengan rute pemberian yang tidak diizinkan oleh lisensi produknya. Pada penelitian ini, ditemukan 7 pasien anak yang mendapatkan salbutamol dalam kategori off-label kategori rute pemberian. Banyak dokter meresepkan tablet salbutamol yang diracik menjadi sediaan puyer untuk anak dibawah 2 tahun. Hal tersebut dikarenakan sediaan salbutamol inhaler tidak tersedia di puskemas. Selain itu pertimbangan lain yakni biaya salbutamol oral lebih murah dibanding inhaler. Akan tetapi penggunaan salbutamol oral untuk mengatasi asma kurang direkomendasikan (Craig et al, 2016). Meskipun demikian, beberapa jurnal menyampaikan bahwa pada kondisi batuk akut, batuk kronik serta kasus bronkhiolitis karena virus, dapat diberikan salbutamol oral (Matera et al, 2017). Akan tetapi, sediaan inhalasi tetap menjadi pilihan yang terbaik karena pemberian secara inhalasi memiliki keuntungan dari pada pemberian secara per oral yaitu memiliki efek yang lebih cepat, dosis yang diperlukan juga lebih rendah sehingga risiko efek samping juga lebih rendah (Akbar et al, 2017).

Obat dikategorikan sebagai obat off-label indikasi jika obat dikonsumsi tidak sesuai dengan indikasi resmi atu lisensi produknya. Obat yang diresepkan secara off-label indikasi pada penelitian ini adalah zink yang secara indikasi resminya merupakan obat untuk mengatasi diare pada anak (Lazzerini et al, 2016). Akan tetapi, zink pada penelitian ini diberikan pada kasus ISPA anak. Secara umum zink digunakan membantu mempercepat penyembuhan diare anak. Akan tetapi menurut Rerksuppaphol et al, menyebutkan bahwa suplementasi zink bermanfaat untuk Acute Lowet Respiratory Tract Infections (ALRI) dan pneumonia berat. Hal ini dikarenakan zink dapat membantu mempersingkat durasi rawat inap serta mengurangi durasi demam dan risiko perawatan (Rerksuppaphol et al, 2019). Kadar zink yang rendah akan berpengaruh terhadap fungsi zink sebagai faktor yang mempengaruhi imunitas tubuh. Defisiensi zink dapat mengakibatkan terjadinya kerusakan epitel saluran nafas, mengganggu fungsi leukosit poli morfonuklear (PMN), sel natural killer, dan aktivasi komplemen sehingga memudahkan anak menderita ISPA (Ferdiansyah, 20I0). Suplementasi zink pada anak dapat mengurangi peradangan, menurunkan obstruksi jalan nafas dan memperpendek durasi penyakit infeksi saluran pernapasan (Rerksuppaphol et al, 2019). Pada penyakit flu yang diakibatkan oleh rhinovirus, pemberian zink dapat menghambat replikasi rhinovirus sehingga dapat mempersingkat durasi dan menurunkan gejala flu (Science et al, 20I2). Efek samping penggunaan zink yang harus dipantau pada pasien anak yaitu rasa ketidaknyamanan perut yang umumnya biasanya bersifat sementara (BNFC, 2019). 
Peresepan off-label merupakan praktik umum dalam pengobatan. Praktik ini dibenarkan jika terdapat bukti ilmiah menunjukkan manfaat dan keamanan obat untuk indikasi yang tidak mendapat persetujuan FDA dan bila praktik tersebut didukung oleh pedoman praktik. Melalui pengambilan keputusan bersama antara pasien dan keluarga dalam proses pengambilan keputusan klinis, maka dokter dan farmasis dengan cermat dapat mempertimbangkan risiko dan manfaat dari pengobatan yang diberikan sesuai dengan kondisi pasien (Furey et al, 2016). Keterbatasan dari penelitian ini adalah tidak dapat melihat data rekam medik pasien di Puskesmas sehingga tidak mengetahui dengan jelas diagnosis penyakit ISPA apakah termasuk jenis pneumonia atau non pneumonia. Data tersebut dapat digunakan sebagai penilaian perlu atau tidaknya pemberian antibiotik terhadap pasien. Data berat badan juga tidak didapatkan pada penelitian ini untuk melihat ketepatan atau kesesuaian dosis obat pada anak. Oleh karena itu, diperlukan penelitian lanjutan dengan mengetahui jenis ISPA yang diderita oleh pasien anak serta melakukan analisis lanjutan faktor-faktor yang menyebabkan penggunaan obat off-label pada pasien anak.

\section{Simpulan}

Kesimpulan pada penelitian ini ialah didapatkan penggunaan off-label pada peresepan penyakit infeksi saluran pernapasan akut untuk pasien anak sebesar $23 \%$ dengan kategori off-label usia (I5,67\%), off-label dosis (5,70\%), off-label rute pemberian (I,22\%) dan off-label indikasi $(0,40 \%)$ dan tidak ditemukan adanya kasus off-label kategori kontraindikasi. Jenis obat off-label paling banyak diresepkan untuk ISPA anak adalah klorfeniramin maleat.

\section{Ucapan Terima Kasih}

Penulis menyampaikan ucapan terima kasih kepada seluruh staf di Puskesmas Wonokusumo, Puskesmas Wiyung, dan Puskesmas Jagir Surabaya yang telah menyediakan tempat dan waktunya untuk pengambilan data penelitian.

\section{Daftar Pustaka}

Akbar, R., Setyaningrum, N., Estiningsih, D. (2017). Kajian Penggunaan Obat Off-label pada Anak di Puskesmas Sleman. INPHARNMED Journal, I(I), 2I-33.

Albrecht HH., Peter VD., Eric PG. (20I7). Role of guaifenesin in the management of chronic bronchitis and upper respiratory tract infections. Multidisciplinary Respiratory Medicine I2:31

Andrzejowski, P., Carroll, W. (2016). Salbutamol in paediatrics: pharmacology, prescribing and controversies Arch Dis Child Educ Pract Ed, IOI:194-I97.

Ballard, CD., Peterson, GM., Thompson, AJ. (2013). "Off-label use of medicines in paediatric inpatients at an Australian teaching hospital." Journal of paediatrics and child health, 49(I), pp.38-42.

British National Formulary for Children. (2018). Edisi 76. British Medical Association and Royal Pharmaceutical Society of Great Britain, London.

British National Formulary for Children. (2019). Edisi 78. British Medical Association and Royal Pharmaceutical Society of Great Britain, London.

British Thoracic Society. (20I4). British Guideline on The Management of asthma, A national clinical guideline, London, UK.

Church, MK., Church DS. (2013). Pharmacology of antihistamines. Indian $J$ Dermatol, 58(3):219-224.

Czarniak, P., Bint, L., Favié, L. (2015). Clinical setting influences off-label and unlicensed prescribing in a paediatric teaching hospital. PloS one, IO(3), p.e0I20630.

de Martino M., Chiarugi A. (20I5). Recent Advances in Pediatric Use of Oral Paracetamol in Fever and Pain Management. Pain Ther, 4(2):I49-168.

Depkes RI. (2005). Pharmaceutical Care untuk Penyakit Infeksi Saluran Pernafasan Direktorat Bina Farmasi Komunitas dan Klinik. Jakarta: Dirjen Bina Kefarmasian dan Alat Kesehatan.

Kemenkes RI. (20II). Buku Bagan Manajemen Terpadu Balita Sakit (MTBS). Jakarta: Kementerian Kesehatan Republik Indonesia Kemenkes RI. (20I3). Riset Kesehatan Dasar. Riskesdas 2013, Badan Penelitian dan pengembangan Kesehatan Kementrian Kesehatan RI, Jakarta.

Kemenkes RI. (2018). Riset Kesehatan Dasar. Riskesdas 2018, Badan Penelitian dan 
pengembangan Kesehatan Kementrian Kesehatan RI, Jakarta.

Depkes. 2009. Profil Kesehatan Indonesia 2008. http://www.depkes.go.id. unduhan pada tanggal I9 september 2020.

Ferdiansyah, HN., Nazir Hz HM., Theodorus. (2010). Hubungan kadar Seng dan Vitamin A dengan kejadian ISPA dan Diare. Sari pediatri, I2(4): 24I-246

Fitzsimons, R., Van Der Poel, A., Thornhill, W. (20I5). Antihistamine use in children. Arch Dis Child Educ Pract Ed, IOO(3);I22-I3I

Furey, K., Wilkins, K. (2016). Prescribing "Offlabel": What Should a Physician Disclose?. AMA Journal of Ethics, I8(6): 587-593

Global Initiative for Asthma (GINA). (20I4). Pocket Guide for Asthma Management and Prevension in Children. Diakses tanggal I0 Desember 2020

Kimland, E., Odlind, V. (2012). "Off-labeldrug use in pediatric patients. Clin Pharmacol Ther, 9I(5);796-80I.

Lazzerini M, Wanzira H. (2016). Oral zinc for treating diarrhoea in children. Cochrane Database Syst Rev, I2(2): CD005436

Malone, M., Kennedy, TM. (2017). Review: Side Effects of Some Commonly Used Allergy Medications (Decongestants, AntiLeukotriene Agents, Antihistamines, Steroids, and Zinc) and Their Safety in Pregnanc. Int J Aller Medications, 3(I)

Matera, MG., Rogliani, P., Zanasi A. (2017). Bronchodilator therapy for chronic cough. Pulm Pharmaco Ther, 47; 88-92.

Purwadi, FV., Rano, KS. (2018). Review: Penggunaan Obat Off-label Pada AnakAnak. Farmaka, I6(I); 54-59

Rajesh, SM., Singhal, V. (2013). Clinical Effectiveness of Co-trimoxazole vs. Amoxicillin in the Treatment of NonSevere Pneumonia in Children in India: A
Randomized Controlled Trial. Int I Prev Med, 4(I0): I I62-II68

Rerksuppaphol, S., Lakkana R. (2019). A randomized controlled trial of zink supplementation in the treatment of acute respiratory tract infection in Thai children. Pediatr Rep, I I(2):7954

Richter P, dalam Wexler P. (20I4). Guaifenesin. Encyclopedia of Toxicology, Edisi ketiga. Academic Press

Saigal, P., Damian, H. (2020). Does zinc improve symptoms of viral upper respiratory tract infection?. Evidence-Based Practice, 23;3739

Science, M., Johnstone J., Loeb M. (2012). Zinc for the treatment of the common cold: a systematic review and meta-analysis of randomized controlled trials. Canadian Medical Association Journal, I84(I0);55I$56 \mathrm{I}$

Setyaningrum, N., Viara, G., Suci G. (2017). Penggunaan Off-label pada Anak di Apotek Kota Yogyakarta. Jurnal Sains Farmasi \& Klinik, 4(2), 30-35.

Tefera, YG., Gebresillassie, BM., Mekuria, AB. (2017). Off-label drug use in hospitalized children: a prospective observational study at Gondar University Referral Hospital, Northwestern Ethiopia. Pharmacology research \& perspectives, 5(2).

Craig S, Tusynski M, Armstrong D. (2016) It is time to stop prescribing oral salbutamol. Aust Fam Physician, 45(4); 245-247

Witch CM, Burkle CM, Lanier WL. (2012). The common question (and their answer) about off-label drug use, Mayo Clinic Proceedings. 